\title{
К ВОПРОСУ О ПОЛИТИЧЕСКОЙ И ПРАВОВОЙ РЕАБИЛИТАЦИИ А. В. КОЛЧАКА: ИСТОРИКО-ГЕОПОЛИТИЧЕСКИЙ КОНТЕКСТ
}

\begin{abstract}
АНнотАЦия. В статье анализируется проблема политической и правовой реабилитации одного из лидеров белого движения в годы гражданской войны А. В. Колчака. На основе историко-геополитического подхода исследуется и оценивается его деятельность. В статье анализируется деятельность Колчака по лоббированию судостроительной программы для военно-морского флота и последствия ее реализации, оценивается его роль в погроме Черноморского флота, тесное сотрудничество с заграницей, участие в иностранных вооруженных формированиях на территории Сибири и Дальнего Востока. Акцентируется внимание на том, что еще до начала Гражданской войны Колчак официально перешел на службу британскому правительству и в качестве назначенного ими «Верховного правителя России» выражал интересы интервентов, не имея ни собственной политической платформы, ни сторонников, ни заслуг в борьбе с большевиками. Основным источником для оценочных суждений и выводов являются признательные показания Колчака, зафиксированные в протоколах чрезвычайной следственной комиссии по его делу. Утверждается, что тенденция к реабилитации личностей, подобных Колчаку, отчетливо проявляющаяся в современной России, создает опасный прецедент для реабилитации подобных деятелей периода Великой Отечественной войны. Отмечается значение историко-геополитического контекста при вынесении правовых вердиктов политическим деятелям.
\end{abstract}

КЛЮЧЕВЫЕ СЛОВА. А. В. Колчак; историко-геополитический подход; интервенция; поддержка иностранных государств; протоколы допроса.

ИНФОРМАЦИЯ О СТАТЬЕ. Дата поступления 21 марта 2017 г.; дата принятия к печати 5 апреля 2017 г.; дата онлайн-размещения 15 июня 2017 г.

\section{A. V. Shalak \\ Baikal State University, Irkutsk, Russian Federation}

\section{ON ISSUE OF POLITICAL AND LEGAL REHABILITATION OF A. V. KOLCHAK: A HISTORICAL AND GEOPOLITICAL ASPECT}

ABSTRACT. The article analyses the problem of political and legal rehabilitation of A. V. Kolchak, one of the leaders of the white movement in the years of the Civil War. In terms of the historical and geopolitical approach, it investigates and evaluates his activity. The article analyses Kolchak's activities in lobbying the shipbuilding program for the Navy and consequences of its implementation, assesses his role in demolition of the Black Sea Fleet, close cooperation with foreign lands, participation in foreign armed formations on the territory of Siberia and the Far East. It focuses attention on the fact that before the beginning of the Civil War Kolchak officially switched over to the British Government service and as "the Supreme Governor of Russia», appointed by them, expressed the interests of the invaders, while having neither his own political platform, no allies, nor merits in struggle against the Bolsheviks. The main recourse for the value judgement and conclusions are confessionary statements made by Kolchak that are fixed in the protocols of the extraordinary commission of inquiry for his case. It is assumed that the tendency of rehabilitating persons like Kolchak, which is distinctly makes itself manifest in modern Russia, sets a precedent for rehabilitation of such figures in the period the Great Patriotic War.

(C) А. В. Шалак, 2017

\section{Baikal Research Journal}


The article notes the significance of the historical and geopolitical context in issuing legal verdicts to political persons.

KEYWORDS. A. V. Kolchak; historical and geopolitical approach; intervention; support of foreign states; protocols of interrogation.

ARTICLE INFO. Received March 21, 2017; accepted April 5, 2017; available online June 15, 2017.

2017 г. - столетие Великой русской революции. Началась она с верхушечного переворота в феврале 1917 г., а закончилось гражданской войной и интервенцией. А. В. Колчак в этих событиях играл не последнюю роль.

В литературе, вышедшей постсоветский период личность Колчака представлена фигурой государственника, радеющего за свое отечество. Особенно такая точка зрения имеет отношение к информационным ресурсам интернет, где представлен светлый и трагический одновременно портрет его личности.

Идеализация А. В. Колчака не увязывается со словами популярной песенки периода Гражданской войны, в которой «правитель омский» отождествлялся с интервентами («Мундир английский, пагон французский, табак японский, правитель омский») [1] и с тем его обликом, который прочно укоренился в 1920-е гг. Сибирские старожилы долгие годы своим самым злым псам давали кличку «Колчак». Не найдем мы в Википедии и рассмотрение аргументов Верховного суда РФ, отказавшего в реабилитации Колчака. А этот отказ связан с такими сторонами деятельности А.В. Колчака, которые упорно стараются не замечать.

Поэтому обращение к личности Колчака вполне актуально и с научной точки зрения и сточки зрения противодействия тем разрушительным мифам, которые системно навязываются в рамках информационной войны, целью которой является переформатирование общественного сознания российского общества.

Исследовать этот вопрос через призму идеологии, невозможно. Внятная идеология была сформулирована только в рамках "красного движения», у «белых" она вообще отсутствовала, что касается Колчака, то и здесь абсолютно невозможно определить, какой идейно-политической программы он придерживался.

Оценить деятельность А. В. Колчака с точки зрения правовых норм, также представляется невозможным. В ряде научных работ такая попытка предпринимается. Примером может служить монография С. В. Дрокова [2]. Проблема, с точки зрения С. В. Дрокова, в том, что допрашивала и судила Колчака Чрезвычайная следственная комиссия, вопрос юридической состоятельности которой остается открытым. Если поставить под сомнение правомочность создания такой комиссии, то, следовательно, возникает вопрос и о юридической состоятельности допросов Колчака. То есть под сомнение ставятся не факты, которые фигурируют в протоколах допроса, а процессуальные нормы. Но с позиций такого «правового подхода», игнорирующего конкретно-исторический контекст, оправдать потребуется всех. Вначале потребуют оправдать «героев» гражданской войны, а затем и Великой Отечественной.

$\mathrm{C}$ нашей точки зрения, создать основу для вынесения политических и правовых вердиктов, наиболее объективно оценить роль той или иной личности возможно только на основе геополитического подхода. С позиций геополитики, в условиях Великой русской смуты главным являлись не идеологические различия, а то, что кому-то были интересны природные ресурсы нашей страны, устранение с рынка конкурента, кто-то рассматривал весь мир в качестве объекта полного политического присвоения.

C установления прямого контроля над сушей в начале XX в. между государствами развернулась ожесточенная борьба за доступ к ресурсам. Одновременно

\section{Baikal Research Journal}


начался быстрый процесс сколачивания различных блоков, поскольку в одиночку бороться за ресурсы невозможно. С этих позиций деятельность политических режимов и различных общественных систем может оцениваться только с позиций обеспечения национальной безопасности, которая оказалась в прямой зависимости от контроля за пространством и его ресурсной базы. Вместе с тем, это является и критерием для оценки политической и государственной деятельности. Именно с такой точки зрения важно рассмотреть и оценить деятельность «Верховного правителя России» А. В. Колчака. В чьих интересах он действовал? В интересах сбережения России, ее безопасности, или играл на стороне ее геополитических противников, стремящихся установить контроль над ресурсами России? Осознанно он это делал, или так получилось случайно, в силу определенных обстоятельств?

Основные ресурсы планеты сосредоточены на евразийском континенте, где в начале XX в. наиболее динамично развиваются две державы: Германия и Россия. Союзнические отношения между ними означали, что именно этим государствам будет принадлежать решающая роль в контроле над ресурсами Евразии, их распределением. Морские государства и прежде всего Великобритания, которая в то время являлась самой крупной державой по территории и численности населения, могла переломить ситуацию в свою пользу, только в случае недопущения такого союза, а еще лучше, если эти государства удастся столкнуть между собой в военном конфликте. Истощение и неизбежное ослабление России и Германии в войне между собой позволяло англосаксонскому миру установить контроль над Евразией. Именно этой геополитической игрой пронизана мировая политика, начиная с конца XIX в. и по сегодняшние дни. Американский геополитик Зб. Бжезинский назвал ее «Великой шахматной доской» [3].

В России имелись политические силы, государственные деятели, которые понимали характер геополитических процессов и стремились не допустить войны России с Германией? Достаточно вспомнить аналитическую записку Петра Николаевича Дурново, министра внутренних дел в начала XX в., которую он направил в адрес Николая II в Феврале 1914 г. [4]. Он отчетливо понимал, что война России с Германией гибельна для обоих государств. Записка уникальна тем, что все предупреждения Н. П. Дурново сбылись.

Можно также напомнить весьма ныне популярные труды Алексея Ефимовича Вандама (Едрихин), генерала военной разведки царской России, автора работ в области геополитики, написанных до начала Первой мировой войны [5;6]. Он аргументировано доказывал, что главным геополитическим противником России являются англо-саксонские народы, которые намерены ослабить ее до пределов возможного, оттеснить от Тихого океана вглубь Сибири. Противостоять этому можно лишь через создание союза сухопутных держав - России, Германии, направленного против «утонченного деспотизма Англии». Хуже войны с англосаксом может быть только дружба с ним, утверждал А. Е. Ядрихин.

Ряды политиков, ученых, государственных деятелей, осознающих геополитические интересы России в начале XX в. достаточно широки.

Однако в этой геополитической схватке начала XX в. англосаксы сумели переиграть всех. Лагерь сторонников союза с Англией оказался в конечном итоге сильнее. Выбор монарха в пользу Антанты завершился величайшей геополитической катастрофой и социальными потрясениями. Сегодня геополитический расклад трансформирован итогами двух мировых войн, распадом советской государственности. В условиях открытой антироссийской истерии и антироссийских санкций вопрос о том, кто «друзья» и, кто «враги» государства российского, отпадает сам собой.

\section{Baikal Research Journal}

электронный научный журнал Байкальского государственного университета 
Какова же была позиция А. В. Колчака в этом геополитическом раскладе? О его деятельности и деятельности «сибирского правительства» собрано огромное количество документов, имеется обширная литература [7-12]. В 2001 г. были изданы наиболее известные исторические и военно-научные труды и воспоминания отца и сына - генерал-майора В. И. Колчака и адмирала А. В. Колчака [13].

Официальный суд над правительством Колчака проходил с 20 по 30 мая 1920 г. в пригороде Омска, в мастерских вагонного цеха, приспособленных для проведения заседаний. Доказательная база опиралась более чем на три тысячи документов [2, с. 274].

Правительство Колчака обвинялось по следующим пунктам: в бунте и восстании при поддержке иностранных государств; в организации истребительной вооруженной борьбы против советской власти; в организации системы массовых убийств против населения; в предательском призыве иностранных вооруженных сил; разрушении достояний советской республики; расхищении и передаче иностранным правительствам достояний советской республики (речь шла о передаче иностранным государствам системы железных дорог Сибири и золотого запаса) [Там же, с. 269].

Об этой стороне деятельности А. В. Колчака его защитники предпочитают молчать. И именно эта деятельность А. В. Колчака по непонятным причинам нашла наименьшее отражение в исторической литературе, в том числе иностранной.

Это, по крайней мере, странно, поскольку имеющиеся источники позволяют составить достаточно определенное представление о сотрудничестве А. В. Колчака с представителями других государств. Основным документом являются протоколы допроса А. В. Колчака. Сам Колчак мемуаров не оставил, но стенограмма допроса отражает различные стороны его жизни. Колчак отвечал на вопросы обширно, по сути, в протоколах допроса с его слов изложена краткая автобиография. Впервые протоколы допроса были опубликованы в Германии в 1920 г., а затем в России в 1925 г. В постсоветской России они опубликованы в 2015 г. [14]. Однако удивительно, что самый ценный источник никак не фигурирует в работах, реабилитирующих А. В. Колчака.

Стремительный взлет карьеры А. В. Колчака начинается с января 1906 г. по его возвращению из японского плена. Колчак с группой офицеров в рамках непонятного «кружка" начинает заниматься «возрождением российского флота» [Там же, с. 14]. С подачи кружка(!) создается Морской Генеральный штаб и предлагается судостроительная программа. Данная программа основывается на следующей оценки военно-политической обстановки: война неизбежна, начнется примерно в 1915 г. Германия в этой войне будет основным врагом России. Ситуация более, чем странная. Определять приоритеты национальной политики, кто «друзья», а кто "враги», должны политики и государственные деятели. В данном случае эту миссию выполняют мало кому известные офицеры во главе с Колчаком, прибывшим из плена.

Совсем молодой офицер, командовавший до этого лишь миноносцем, вдруг «предлагает правительству организовать Морской Генеральный штаб», и его предложение принимают. Колчака буквально "раскручивают» СМИ, в высоких кругах звучат его доклады. Столь стремительные карьерные взлеты вызывают подозрения, наводят на мысль, что его проталкивала некая внешняя сила.

Первый опыт общения Колчака с заграницей произошел в годы русско-японской войны 1904-1905 гг. Эту войну Япония поостереглась бы развязать, если бы не открытая поддержка со стороны Великобритании и США. Озабоченные укреплением позиций России на Дальнем Востоке, Англия и США стремились, используя Японию, ослабить ее позиции. В российских газетах печатались мно-

\section{Baikal Research Journal}

электронный научный журнал Байкальского государственного университета 
гочисленные карикатуры на тему поддержки Японии со стороны англосаксов. Германия в этой войне выступала на стороне России. Не знать этого расклада А. В. Колчак не мог.

Колчак побывал в плену у японцев. О своем нахождении в плену Колчак на допросе рассказывает следующее: «В Нагасаки партия наших больных и раненых получила очень великодушное предложение японского правительства, переданное Французским консулом, о том, что правительство Японии предоставляет нам возможность пользоваться, где мы захотим, водами и лечебными учреждениями Японии, или же, если мы не желаем оставаться в Японии, вернуться на родину без всяких условий. Мы все предпочли вернуться домой» $[14$, с. 23]. Отметим здесь такие детали: с пленными работают представители союзников Японии и обращаются с ними «великодушно». В Россию Колчак прибывает, побывав после плена в США и Англии. Колчак не объясняет, почему он не вернулся в Россию через Владивосток по железной дороге. И вот затем, посетив США и Англию, Колчак вдруг в рамках какого-то интересного кружка, который он сам именует «полуофициальный» [Там же, с. 22], претендует на то, чтобы определять морскую стратегию Россию. И при этом он убеждает, что война будет с Германией.

Следует напомнить, что именно в это время разворачивается острейшая борьба за создание стратегических блоков, Великобритания делают все возможное, чтобы стравить Россию с Германией. И в этой борьбе Колчак по странной логике не на стороне союза с Германией, которая поддерживала Россию в войне с Японией, а на стороне англосаксов.

О деятельности разведслужб, значении шпионской деятельности Колчак был хорошо осведомлен. Обучаясь в Николаевской морской академии в 1911-1912 гг. он пишет пространный доклад «Служба Генерального штаба», в котором подробно излагает способы получения военных сведений от иностранных государств. Этот доклад впервые был приведен в приложении монографии С. В. Дрокова [2, с. 373-474]. Со знанием дела Колчак пишет о подготовке шпионов, участии офицеров в тайной разведке, тайных разведывательных органах, военном и военно-политическом шпионстве.

О предложенной судостроительной программе Колчак на допросе говорит обтекаемо, не вдаваясь в подробности. При этом не забывает упомянуть, что он неоднократно выступал экспертом на совещаниях, заседаниях различных комиссий Государственной Думы и т. д. То есть он не отрицает того, что выступал лоббистом определенной судостроительной программы, более того, именует себя основным разработчиком этой программы.

Что из себя представляла судостроительная программа, пролоббированная «младореформаторами» во главе с Колчаком? В условиях, когда средства на строительство флота были предельно ограничены, Колчак выступил за строительство линкоров для русского флота. Линкоры должны были быть построены в ущерб минным заградителям и тральщикам, подводным лодкам и броненосцам береговой обороны, береговым батареям, миноносцам, крейсерам и прочим кораблям, судам, силам и средствам. Основной довод Колчака: Россия, чтобы считать себя великой страной, тоже должна иметь линкоры, поскольку их имеют Англия, Франция, Германия.

Но в отличие от этих стран, Россия не имела военно-морских баз, называвшимися тогда также угольными станциями. Следовательно, линкоры, предназначенные для действий в составе эскадр на большом удалении от родных берегов, Россия не могла использовать. Для линкоров нужны угольные станции. В такой ситуации российские линкоры могли быть использованы только на внутренних морях - Балтийском и Черном. Но запертые в бассейнах этих морей, они стано-

\section{Baikal Research Journal}

электронный научный журнал Байкальского государственного университета 
вились чрезвычайно уязвимыми для подводных лодок, вооруженных торпедами. Если бы даже маленькая часть денег, потраченных на строительство линкоров, была направлена на строительство подводных лодок, то подводный флот России не позволил бы перемещаться вражеским кораблям в наших морях.

Поэтому в итоге реализации данной программы даже на Балтике Россия была не способной противостоять германскому или английскому флоту в открытом бою. По прямому назначению линкоры использованы так и не были. Линкоры на Балтике стреляли только по осадным батареям фашистов во время блокады Ленинграда. Таким образом, реализация данной программы привела к тому, что морское господство Великобритании не было поколеблено, а уязвимость нашего флота даже во внутренних морях возросла в связи с угрозой со стороны подводного флота [15]. При этом в статье «Какой флот нужен России», опубликованной в журнале «Морской сборник» в 1908 г., Колчак утверждает, что «Флот Англии на всех наших морях нам непосредственно не угрожает», и что для России «...создание мощной силы, способной бороться за обладание морем в Тихом океане, едва ли является целесообразным» [16]. С позиций подобных заявлений создание линкорного флота смотрится вообще полной бессмыслицей. Колчак настаивает на строительстве линкоров, но они не должны бороздить океанские просторы и тем более не присутствовать в районе Тихого океана. Напомню, что русский геополитик Ядрихин, аргументировано доказывал, что англо-саксы намерены уничтожить торговый и военный флоты России, ослабить ее до пределов возможного, оттеснить от Тихого океана вглубь Сибири. И деятельность Колчака ка-то удивительно целостно совпадает с их стратегией.

Поэтому и начало войны с Германии с Россией Колчак встречает «с громадным энтузиазмом и радость..., и вообще начало войны было одним из самых счастливых и лучших дней моей службы». [14, с. 34]. Геополитическая трагедия России для Колчака оборачивается самой большой радостью.

Шаги, предпринятые Колчаком в годы смуты, также никак не ассоциируются с деятельностью, направленной на укрепление российской государственности. Обратимся к протоколам допроса. Отвечая на вопросы, Колчак утверждает, что он по своим взглядам оставался монархистом: «Я откровенно должен сказать, что ни в отношении династии, ни в отношении личности императора у меня никаких вопросов не возникало... Как военный, я считал обязанностью выполнять только присягу, которую я принял, и этим исчерпывалось все мое отношение. ...Я был монархистом и нисколько не уклоняюсь... Я считал себя монархистом и не мог считать себя республиканцем» [Там же, с. 53-54, с. 56-57].

Но после февральского переворота Колчак мгновенно «забывает» о присяге и о своих монархических пристрастиях. Из высшего командования (четыре командующих фронтами и двое командующих флотами) он первым, опередив даже заговорщиков, присягнул Временному правительству. «Когда совершился переворот, я получил извещение о событиях в Петрограде и о переходе власти к Государственной Думе непосредственно от Родзянко, который телеграфировал мне об этом. Этот факт я приветствовал всецело», - свидетельствует Колчак [Там же, с. 58].

А что же с монархией? «Я считал себя совершенно свободным от всяких обязательств по отношению к монархии, и после совершившегося переворота стал на точку зрения, на которой я стоял всегда, - что я, в конце концов, служил не той или иной форме правительства, а служу родине своей, которую ставлю выше всего, и считаю необходимым признать то правительство, которое объявило себя тогда во главе российской власти» [Там же, с. 58-59].

Затем, так же легко, Колчак обнулил свою присягу Временному правительству. Будучи командующим Черноморским ВМФ, бросил флот на произвол судь-

\section{Baikal Research Journal}

электронный научный журнал Байкальского государственного университета 
бы, усугубив хаос в российской армии. Таковы «убеждения» и «приверженность присяге» Колчака. В воюющей стране происходит государственный переворот, обнулилась присяга, что стало прологом к смуте, и Колчак всецело поддерживает этот процесс своими действиями. Когда делегатское собрание флота поставило вопрос о разоружении офицеров, Колчак отбил телеграмму 7 июня в Петроград, в которой обиженно заявлял, что в этих условиях он не может командовать, ему нанесено оскорбление, он снимает с себя все полномочия [14, с. 101]. И делает он все это еще до того, как делегация Совета потребует от него отказаться от командования Флотом. Как известно, ситуация с Черноморским флотом в конечном итоге закончилась катастрофой: половина флота была затоплена командами, остальные попали в руки немцев и были уведены в различные порты. На Черном море российский флот практически был уничтожен. В отличие от него, Балтийский флот сохранил боеспособность, активно сопротивлялся и сыграл исключительно важную роль в отражении германского наступления на северо-западном направлении.

Колчак, как «допустивший бунт», был призван отчитаться в Петрограде перед Временным правительством. На заседании правительства, которому Колчак присягнул первым и на котором от него потребовали объяснений о его добровольном сложении полномочий командующего флотом, заявляет, что нужно «...просто-напросто распустить команды и прекратить деятельность Флота, потому что при таких условиях Флот все равно никакой пользы не принесет» [Там же, с. 104]. Позиция больше, чем интересная. Командующий флотом совсем недавно заявлял, что он готов бороться до конца, чтобы довести войну до победного конца, что именно «поэтому я приветствовал революцию, как возможность рассчитывать на то, что она внесет энтузиазм... в народные массы и даст возможность закончить победоносно эту войну, которую я считал самым главным и самым важным делом, стоящим выше всего, - и образа правления, и политических соображений» [Там же, с. 59]. И вот вместо того, чтобы сделать все возможное для доведения войны до победного конца, он в знак «протеста» против революции, которую только что приветствовал, покидает Флот.

Таким образом, роль Колчака в погроме Черноморского флота вполне очевидна. В этом деле есть еще один интересный аспект. Колчак добровольно отказывается командовать флотом за день перед приездом американского контрадмирала Дж. Гленнона. Гленнон был в составе специальной дипломатической миссии США, отправленной президентом Вильсоном в Россию. Основной целью миссии являлось ознакомление с ситуацией в стране и предотвращение выхода России из войны. Миссия прибыла в Россию в мае 1917 г. В начале июня американская делегация прибыла в Севастополь. Дж. Гленнон прибывает в Севастополь для встречи с Колчаком. Обратно в Петроград они возвращаются уже вместе в одном вагоне. И затем американский адмирал инициирует поездку Колчака в США.

В отечественной историографии нет ни одной работы, посвященной военно-морской миссии Колчака в США. А ведь из этого вытекает одно из основных обвинений в отношении Колчака - его продажность интересам западных государств. Особенно на это указывали историки в 1920-е гг.

С какой стороны Колчак мог заинтересовать американцев? В годы Первой мировой войны был разработан детальный план по нейтрализации турецкого ВМФ через контроль за Босфором. Окончательный контроль за проливами в соответствии с этим планом должен был быть осуществлен в 1917 г. Совместное наступление сил коалиции против Германии и ее союзников должно было начаться в апреле 1917 г., по итогам войны, контроль за Дарданеллами должен был перейти к России. Но по странному стечению обстоятельств, в феврале 1917 г. в России совершается государственный переворот. Адмирал Колчак несомненно был посвя-

\section{Baikal Research Journal}

электронный научный журнал Байкальского государственного университета 
щен в детали разрабатываемого плана по установлению контроля за проливами. Знание Колчаком турецких фортификаций, его опыт в постановке минных заграждений, не могли не интересовать США. США не меньше России были заинтересованы в контроле над черноморскими проливами. Именно поэтому с адмиралом встречаются глава американской миссии сенатор И. Рут и контр-адмирал Дж. Гленнон. Они предлагают адмиралу поехать в США для участия в разработке плана захвата проливов. Колчак соглашается и расценивает это как поступление на американскую службу [2, с. 156]. Он полагал, что его знания будут востребованы американцами и тем самым он сможет занять вполне достойную должность в американском флоте, поучаствовать в установлении контроля над Босфором и Дарданеллами на стороне США. Сей «патриот» этого и не скрывает: «...у меня была тогда надежда, что я буду принимать известное участие в Дарданелльских операциях" [14, с. 108].

Колчак не скрывал, что целью его поездки в США являлось сдача российских планов по установлению контролю над черноморскими проливами. В протоколах допроса по этому пункту он повествует следующее: «Кроме того, совершенно секретно он (адмирал Гленнон) сообщил мне, что в Америке существует предположение, предпринять активные действия американского Флота в Средиземном море против турок и Дарданелл. Зная, что я занимался аналогичными операциями, адмирал Гленнон сказал мне, что было бы желательно, чтобы я дал все сведения по вопросу о десантных операциях в Босфоре. Я ответил на это, что не отказываюсь от этого и готов поделиться теми сведениями, которые у меня имеются... Относительно этой десантной операции он просил меня никому ничего не говорить и не сообщать об этом даже правительству» [Там же, с. 106]. Колчак на допросе не скрывает своих доверительных отношений с американцем, и он прекрасно осознает, что от него требуют предательства.

Дж. Гленнон уехал, а Колчак решительно отвергает все предложения вновь возглавить флот и готовится к отъезду в США. При этом в своем стремлении добиться разрешение на поездку США Колчак проявляет фантастическую целеустремленность и настойчивость, совсем не похожие на его позорное бегство с Черноморского флота. В итоге он добивается личной встречи с А. Ф. Керенским и тот дает свое согласие на отъезд Колчака в США. Пока решался вопрос о его поездке и оформлении паспорта, Колчак, как он повествует сам, «...начал подбирать все материалы, необходимые для этой задачи» [Там же, с. 106].

О планах Колчака и цели его поездки в США были проинформированы и англичане. «Что касается моего отправления в Америку, то оно находилось в тесной связи с согласием английского правительства.... я вошел в сношения с английской миссией, сказал им откровенно о цели моей поездки» [Там же, с. 118]. И именно англичане через свои пункты контроля обеспечили безопасный выезд адмирала из России через Швецию под чужой фамилией. Вся это ситуация с отъездом Колчака очень напоминает детективную история по вывозу провалившихся, но ценных агентов из страны, где им находится опасно. Прибыв первоначально в Лондон, Колчак встречается там с британским военным министром, а затем начальником штаба британского флота. Очевидно соответствующая информация от Колчака уходит и здесь. Англичан больше всего волнует северно-балтийский театр военных действий и нет никаких сомнений, что всю информацию они от Колчака получили. «Джелико беседовал со мною очень долго по поводу обороны Немецкого моря и минирования немецких берегов» [Там же, с. 121]. Колчак конечно ничего не говорит о содержании своих встреч с британскими партнерами, но очевидно, что рассматривались и вопросы чисто политические. Генерал Холл в своих беседах, свидетельствует Колчак, говорил, что Россию «может спасти только военная дик-

\section{Baikal Research Journal}

электронный научный журнал Байкальского государственного университета 
татура» [14, с. 121]. Немного погодя, именно Колчаку они уготовят роль диктатора. А сам характер бесед свидетельствует, что Колчак уже ведет себя так, как будто он является не адмиралом российского флота, а находится на службе у англосаксов. Был ли он завербован, или желает служить добровольно - это уже второстепенно.

В США Колчака также встречали как очень нужного человека. Для его проезда выделили специальный вагон, все обслуживание и проживание осуществлялось за счет американского правительства. Несколько недель Колчак передавал нужную информацию американцам. Когда те вытянули из него все, отношение к нему изменилось. Надежды на то, что он будет востребован американцами в операции по контролю над черноморскими проливами не оправдались. Американский флот в ближайшее время $\kappa$ реализации данного плана был не готов, да и в случае его реализации места там для Колчака, очевидно, не находилось. Отношение к Колчаку стало достаточно прохладным. И он не мог этого не чувствовать. Иллюзии в плане применения себя на службе американского государства растаяли. «Я был глубоко разочарован, так как мечтал продолжать свою боевую деятельность, но видел, что отношение в общем к русским тоже отрицательное» [Там же, с. 124].

Тогда Колчак принимает решение вернуться опять в Россию. Обратный путь его лежал через Японию и Владивосток. При этом уже до отъезда Колчак знает об очередной смене власти в России, что Временное правительство пало. Но решение о переходе на военную службу Великобритании он принимает, будучи в Японии. По крайнем мере, так он утверждает во время допросов. Он просит принять его в английскую армию «на каких угодно условиях» [Там же, с. 128]. В итоге он получает назначение в Индию на месопотамский фронт. Колчак отбывает по месту своего назначения. Однако в Сингапуре его догоняет новая телеграмма из генерального штаба Великобритании о том, что ему «рекомендуется ехать на Дальний Восток, начать там свою деятельность» [Там же, с. 136].

Таким образом, на Дальнем Востоке Колчак оказывается не как идейный противник большевиков, а как человек, находящийся на службе у Великобритании и выполняющий команды и указания британского правительства. С этих позиций жестокость и насилие со стороны колчаковских войск, находящихся под контролем «союзников», вполне объяснима. Крестьянство Сибири и малочисленные рабочий класс воевать на стороне интервентов не желали. Загнать их в войско А. В. Колчака, обеспечить тыловое обеспечение, необходимый объем провианта можно было только посредством репрессий и насилия. Местное население прекрасно осознавало, кого представляет Колчак и на чьей стороне он воюет. Пытаясь оправдаться, на допросе Колчак рисует картину своей беспомощности противостоять карательным отрядам, грабившим и расстреливающим местное население за любое неповиновение.

Англичане, как всегда, предпочитали действовать через других лиц. Войска интервентов в Сибири и на Дальнем Востоке представляли внушительную силу. Однако бремя ведения прямых военных действий они возложили на русских. Англичане выделяли средства, формировали и спонсировали различные вооруженные отряды для борьбы с большевиками. Однако не хватало в этой работе координации, не было человека, способного выполнить предназначенную англичанами роль «Верховного правителя». И именно в этой ситуации они сделали ставку на Колчака. И Колчак с этой ролью соглашается. Естественно, что назначенного «Верховного правителя» признают и все другие лидеры белого движения, поскольку все они спонсируются из-за рубежа. Без открытой поддержки белого движения со стороны «союзных государств», не было бы никакой гражданской войны. Деньги на интервенцию Сибири и Дальнего Востока давали Англия и Франция, а оружие на них закупали в Японии.

\section{Baikal Research Journal}

электронный научный журнал Байкальского государственного университета 
Из Японии во Владивосток А.В. Колчак добирается в сопровождении Ренью, возглавлявшего французскую "дипломатическую миссию» [14, с. 228]. А в октябре 1918 г. в Омск его доставляет английский генерал А. Нокс (они прибыли с ним вместе в одном купе). Четвертого ноября «союзники» назначают Колчака военным и морским министром «Сибирского правительства». То есть назначают «командовать» собранными и вооруженными «союзниками» антибольшевистскими силами человека, который не имеет ни сторонников, ни заслуг в борьбе с большевиками, ни команды. Колчак постоянно на допросе ссылается на то, что ему очень хотелось выполнить союзнические обязательства России в войне с Германией, и этим он пытается оправдать свое поступление на военную службу к англичанам. Но англичане его направили бороться с русским народом на стороне интервентов, а не с армией Германии.

В Сибири в это время заправляют «союзные войска». Чехи подчиняются им, контролируя железнодорожную магистраль. На всех совещаниях колчаковского правительства и командования присутствуют представители иностранных государств. Колчак постоянно проговаривается об этом, давая показания на допросе. Фактически он всегда находится в сопровождении и под присмотром «союзников». Колчак не скрывает, что у него очень близкие отношения с представителем англичан Уордом. Тот даже конвой из англичан по просьбе Колчака выделяет для сопровождения арестованных членов Директории [Там же, с. 224-225]. Во время переворота также в Омске присутствовали все представители союзных государств: от США - Гаррис, Франции - Реньо, Англии - Уорд. Со стороны Японии была военная миссия. Представителями от чехов были тогда Кошек и Рихтер. Как они оценили деятельность Колчака? Колчак свидетельствует, что отношение сей союзных друзей к нему «были самыми положительными» [Там же, с. 234]. Колчак, конечно, лукавит, когда заявляет, что его действия для них явились полной неожиданностью. Зная, на службе какого государства он находился и кем он был направлен на Дальний Восток, говорить о том, что представители союзных государств ничего не ведали - наивно. На наивного человека Колчак не похож и по ходу допроса неоднократно отмечает, что реальная власть и координация действий всех вооруженных формирований на Дальнем Востоке принадлежала представителям союзных государств. На многочисленных фото этого периода Колчак, как правило, в окружении представителей союзных войск. Поезд, на котором Колчак отправился из Омска на Уральский фронт охранял английский конвой. Из Омска в Иркутск Колчак отправляется в купе, декорированном флагами Великобритании, США, Франции, Японии и Чехословакии.

То, что его союзники предали и продали, поскольку он оказался в той ситуации им бесполезен, так это привычное дело для англосаксов. Без власти и войска, способного бороться с Красной армией, Колчак никакой ценности для союзников не представлял. Ценность в данном случае для них представляло только золото.

17 декабря 1919 г. чехи останавливают железную дорогу. На восток пропускают только эшелоны с чехами. В Красноярске отбирают паровоз даже у Колчака. И Колчак («Верховный правитель России») ничего не может сделать. Он шлет телеграмму союзника («представителям великих держав») и просит их «воздействовать» на чехов [2, с. 84-85]. Данная ситуация, как никакая другая, характеризует истинное «величие» Колчака и указывает на то, что заправляют ситуацией интервенты. С этих позиций понятно, почему войско Колчака, в котором было то ли 700, то ли 500 тыс., то ли 300 тыс. человек ничего не может поделать с 30 тысячным войском чехов.

Главнокомандующий войсками Колчака Капель пытается заступиться за «Верховного правителя». Он направляет в Иркутск 18 декабря телеграмму Сыровому,

\section{Baikal Research Journal}

электронный научный журнал Байкальского государственного университета 
в которой требует от того извинится перед Колчаком за нанесенные такими действиями оскорбления «Верховному правителю» и более того грозит ему дуэлью [2, с. 83-84].

21 декабря на «рыцарско-патриотическую» телеграмму Капеля откликается из Забайкалья Семенов, который готов занять место у барьера вместо Каппеля [Там же, с. 84-86]. Эти люди понимают, о чем идет речь. Крах Колчака, ставит под сомнение и их политическое бытие. Поэтому они пытаются проявить нечто вроде твердости, выражая ему поддержку. Семенов на выручку Колчаку 30 декабря отправляет отряд под начальством генерал-майора Скипетрова с целью занять ст. Иркутск. Однако отряд встречают кинжальным огнем не партизаны и воинские формирования Политцентра, а доблестные чехи, которыми командуют французский генерал Жанен, бывший главнокомандующий всеми «союзными» войсками в России. Они разгоняют паровоз навстречу бронепоезду семеновцев, на железной дороге авария, пути перегорожены.

15 января арестованные в Нижнеудинске Колчак и Пепеляев (всего 112 человек) сняты с поезда и переданы Политцентру. Допрашивать Колчака начинают 20 января. 24 января Иркутскому отделению Госбанка передается мешок с золотом и бриллиантами, отобранными из поезда Колчака [Там же, с. 88].

У эсеров и меньшевиков (а также примкнувших к ним крестьянского союза и политического земского бюро), захвативших Колчака, был свой план: создать Сибирскую республику от Оби до Восточных окраин. Они и создали в Иркутске свое правительство - Политцентр. Красные войска вошли в Иркутск через две недели после казни Колчака. При этом земцы считали, что и большевики, и Колчак узурпаторы. Но большевики захватили власть в интересах беднейших слоев населения России, а Колчак опирается на поддержку иностранцев. Именно поэтому они стремились к установлению договорных отношений с советской властью, чтобы объединить усилия в борьбе с интервентами.

При этом Политцентр брал на себя обязательство арестовать штаб Колчака и передать его и золотой запас Советской России. Но Колчака не передали, а его и В. Н. Пепеляева расстреляли в Иркутске.

Такова судьба этого человека. Колчака погубили не столько действия его врагов, не столько пренебрежение его «союзных друзей», сколько собственное предательство. Когда верхушечно-военный переворот в октябре 1917 г. перерос в гражданско-отечественную, а затем национально-освободительную войну, в которой решалась судьба России, Колчак открыто перешел на сторону тех иностранных сил, с которыми российская империя всегда сражалась и с которыми геополитическое противостояние продолжается сегодня. Это был его личный выбор, о мотивах которого можно строить различные предположения. И этот выбор закончился для него личной катастрофой. В данном случае его действия ничем не отличаются от тех предателей, которые воевали со своим населением под командованием различных «гауляйтеров» в годы Великой Отечественной войны.

Следует отметить, что тенденция к реабилитации личностей, подобных Колчаку, отчетливо проявляется в постсоветской России. Появляются информационные материалы, оправдывающие лидеров «белого движения». В отношении А. В. Колчака распространяется односторонняя информация о его вкладе в науку и просветительской деятельности, о роли его правительства в открытии Иркутского государственного университета. При этом ничего не говорится о геноциде в отношении населения Сибири, о предательской антигосударственной, антироссийской политике «Верховного правителя». Это создает очень опасный прецедент для реабилитации подобных деятелей периода Великой Отечественной войны. В России это начинается с установления мемориальной доски Маннергейму и памятника

\section{Baikal Research Journal}

электронный научный журнал Байкальского государственного университета 
Краснову, воевавших на стороне гитлеровской Германии, а на Украине уже заканчивается повсеместным переименованием улиц в честь Бандеры и таким же повсеместным установлением ему памятников. Поэтому вынесение политических и правовых вердиктов без опоры на историко-геополитический контекст неизбежно ведет к игнорированию национально-государственных интересов и утрате стратегических приоритетов.

\section{Список использованной литературы}

1. Вишневский Вс. Красный флот в песнях (Героическая поэма-оратория) // Собрание сочинений : в 5 т. / Вс. Вишневский. - М. : Гослитиздат, 1954. - Т. 1. - С. 72-73.

2. Дроков С. В. Адмирал Колчак и суд истории / С. В. Дроков. - М. : Центрполиграф, 2009. $-591 \mathrm{c}$.

3. Бжезинский 3. Великая шахматная доска: американское превосходство и его геостратегические императивы / З. Бжезинский ; пер. с англ. О. Ю. Уральской. - М. : Междунар. отношения, 2010 . $-254 \mathrm{c}$.

4. Дурново П. Н. Записка Дурново Петра Николаевича императору Николаю II [Электронный pecypc] / П. Н. Дурново // LiveJournal. - Режим доступа: http://papanya77. livejournal.com/58244.html.

5. Вандам А. Наше положение (1912) / А. Вандам // Неуслышанные пророки грядущих войн / А. Вандам, Н. Головин, А. Бубнов. - М. : АСТ; Астрель, 2004. - С. 41-118.

6. Вандам А. Величайшее из искусств: обзор современного международного положения при свете высшей стратегии (1913) // Наше положение / А. Вандам. - СПб. : Наука, 2009. - $176 \mathrm{c}$.

7. Богданов К. А. Адмирал Колчак : биогр. повесть-хроника / К. А. Богданов. - СПб. : Судостроение, 1993. - $304 \mathrm{c.}$

8. Краснов В. Г. Колчак: и жизнь, и смерть за Россию : в 2 кн. / В. Г. Краснов. - М. : Олма-Пресс, 2000. - Кн. 1. -431 с. ; Кн. 2. -353 с.

9. Лавров В. В. Адмирал А. В. Колчак (Из крымского периода) / В. В. Лавров // Черноморский Флот в судьбе России : материалы Междунар. конф. Севастополь, 26 окт. 1 нояб. 1997 г. - Симферополь : Крым. Архив, 2000. - 149 с.

10. Мельгунов С. П. Трагедия адмирала Колчака : в 2 кн. / С. П. Мельгунов. - М. : Айрис-пресс, 2004. - Т. 1. - 569 с. ; Т. 2. - 492 с.

11. Плотников И. Ф. Александр Васильевич Колчак: жизнь и деятельность / И. Ф. Плотников. - Ростов н/Д. : Феникс, 1998. - 320 с.

12. Синюков В. В. Александр Васильевич Колчак как исследователь Арктики / В. В. Синюков. - М. : Наука, 2000. - 328 с.

13. Колчак В. И. Избранные труды / В. И. Колчак, А. В. Колчак ; сост. В. Д. Доценко. - СПб. : Судостроение, 2001. - 384 с.

14. Адмирал Колчак. Протоколы допроса / сост. и предисл. Н. Старикова. - СПб. : Питер, 2015. - 272 с. - (Николай Стариков рекомендует прочитать).

15. Рыбин В. В. Каким стратегом был адмирал Колчак [Электронный ресурс] / В. В. Рыбин // Партия Великое Отечество. Блог Николая Старикова. - Режим доступа: https:// nstarikov.ru/blog/65931.

16. Колчак А. В. Какой флот нужен России [Электронный ресурс] / А. В. Колчак // Армия и Флот. - 2002. - № 1 (149). - Режим доступа: http://www.armiyaiflot.ru/ nomera/2002/20021-02.html.

\section{References}

1. Vishnevskii Vs. The Red Fleet in songs (heroic poem-oratory). In Vishnevsky Vs. Sobranie sochinenii [Collection of Works]. Moscow, Goslitizdat Publ., 1954, vol. 1, pp. 72-73. (In Russian).

2. Drokov S. V. Admiral Kolchak i sud istorii [Admiral Kolchak and the Bar of History]. Moscow, Tsentrpoligraf Publ., 2009. 591 p.

3. Brzezińsky Zbigniew. The Grand Chessboard: American Primacy and its Geostrategic Imperatives. New York, Basic books, 1997. 223 p. (Russ. ed.: Brzeziński Z. Velikaya shakhmat-

\section{Baikal Research Journal}


naya doska: amerikanskoe prevoskhodstvo i ego geostrategicheskie imperativy. Moscow, Mezhdunarodnye otnosheniya Publ., 2010. 254 p.).

4. Durnovo P. N. The memo of Petr Nikilayevich Durnovo to Emperor Nicholas II. Live Journal. Available at: http://papanya77.livejournal.com/58244.html. (In Russian).

5. Vandam A. Our situation (1912). In Vandam A., Golovin N., Bubnov A. Neuslyshannye proroki gryadushchikh voin [The unheard prophets of the forthcoming wars]. Moscow, AST Publ., Astrel' Publ., 2004, pp. 41-118. (In Russian).

6. Vandam A. The greatest of arts: review of current international situation in light of grand strategy (1913). In Vandam A. Nashe polozhenie [Our situation]. Saint Petersburg, Nauka Publ., 2009. 176 p. (In Russian).

7. Bogdanov K. A. Admiral Kolchak. Biograficheskaya povest'khronika [Admiral Kolchak: biographical novella-chronicle]. Saint Petersburg, Sudostroenie Publ., 1993. 304 p.

8. Krasnov V. G. Kolchak: i zhizn', i smert' za Rossiyu [Kolchak: both life and death for Russia]. Moscow, Olma-Press, 2000. Vol. 1. 431 p.; vol. 2. 353 p.

9. Lavrov V. V. Admiral A. V. Kolchak (from the Crimean period) Chernomorskii Flot $v$ sud'be Rossii. Materialy Mezhdunarodnoi konferentsii. Sevastopol, 26 oktyabrya - 1 noyabrya 1997 g. [The Black Sea Fleet in Russia's destiny. Materials of International Research Conference. Sevastopol, October 26 - November 1, 1997]. Simferopol, Krymskii Arkhiv Publ., 2000. 149 p. (In Russian).

10. Mel'gunov S. P. Tragediya admirala Kolchaka [Tragedy of Admiral Kolchak]. Moscow, Airis-press, 2004. Vol. 569 p.; vol. 2. 492 p.

11. Plotnikov I. F. Aleksandr Vasil'evich Kolchak: zhizn' i deyatel'nost' [Aleksandr Vasilyevich Kolchak: Life and Activities]. Rostov-on-Don, Feniks Publ., 1998. 320 p.

12. Sinyukov V. V. Aleksandr Vasil'evich Kolchak kak issledovatel' Arktiki [Aleksandr Vasilyevich Kolchak as an explorer of the Arctic Regions. Moscow, Nauka Publ., 2000. 328 p.

13. Kolchak V. I., Kolchak A. V.; Dotsenko V. D. (ed.). Izbrannye trudy [Selected works]. Saint Petersburg, Sudostroenie Publ., 2001. 384 p.

14. Starikov N. (ed.). Admiral Kolchak. Protokoly doprosa [Admiral Kolchak. Protocols of interrogation]. Saint Petersburg, Piter Publ., 2015. 272 p.

15. Rybin V. V. What strategist was. Partiya Velikoe Otechestvo. Blog Nikolaya Stariko$v a$ [Party of Great Homeland. Blog of Nikolay Starikov]. Available at: https://nstarikov.ru/ blog/65931. (In Russian).

16. Kolchak A. V. What kind of fleet Russia needs. Armiya $i$ Flot $=$ Army and Fleet, 2002, no. 1 (149). Available at: http://www.armiyaiflot.ru/nomera/2002/20021-02.html. (In Russian).

\section{Информация об авторе}

Шалак Александр Васильевич - доктор исторических наук, профессор, заведующий кафедрой истории и международных отношений, Байкальский государственный университет, 664003, г. Иркутск, ул. Ленина, 11, e-mail: Shalak-av@bgu.ru.

\section{Author}

Alexandr V. Shalak - Doctor habil. (History), Professor, Head of Chair of History and International relations, Baikal State University, 11 Lenin St., 664003, Irkutsk, Russian Federation; e-mail: Shalak-av@bgu.ru.

\section{Библиографическое описание статьи}

Шалак А. В. К вопросу о политической и правовой реабилитации А. В. Колчака: историко-геополитический контекст / А. В. Шалак // Baikal Research Journal. — 2017. — T. 8, № 2. - DOI: 10.17150/2411-6262.2017.8(2).2.

\section{Reference to article}

Shalak A. V. On issue of political and legal rehabilitation of AS. V. Kolchak: a historical and geopolitical aspect. Baikal Research Journal, 2017, vol. 8, no. 2. DOI: 10.17150/24116262.2017.8(2).2. (In Russian).

\section{Baikal Research Journal}

